\title{
Rainhas, princesas e donas: formas de poder político das mulheres na África Oriental nos séculos XVI a XVII *
}

\author{
Eugenia Rodrigues**
}

\begin{abstract}
Resumo
Este artigo discute o papel das mulheres enquanto actores políticos na região correspondente hoje, grosso modo, a Moçambique, mas também a parte do Zimbabué, Zâmbia e Maláui, entre os séculos XVI e XVIII. Partindo da literatura sobre os estados pré-coloniais e de documentação portuguesa, mostra-se como as mulheres tiveram uma participação activa nas estruturas políticas, agindo como conselheiras, governando nos interregnos, assumindo a chefia de grupos e territórios. As formas de autoridade que as mulheres desenvolveram nestas sociedades, e que se estenderam à sociedade colonial, exigem estudos mais aprofundados.
\end{abstract}

Palavras-chave: Mulheres Governantes, Género, Política, História, África Oriental.

* Recebido para publicação em 31 de agosto de 2016, aceito em 30 de janeiro de 2017.

** Investigadora do Centro de História da Universidade de Lisboa (UID/HIS/04311/2013) e professora na Faculdade de Letras da mesma universidade, Lisboa, Portugal. sazora@sapo.pt 
Queens, Princesses and Donas. Forms of Women Political Power in East Africa of The Sixteenth to Eighteenth Centuries

\begin{abstract}
This article discusses the role of women as political actors in the region corresponding nowadays, roughly, to Mozambique, but also part of Zimbabwe, Zambia and Malawi, from the sixteenth to eighteenth centuries. Based in the literature on the pre-colonial states and Portuguese archival sources, this article highlights how women participated actively in political structures, acting as counselors, ruling in the interregnum, assuming the leadership of groups and territories. The forms of political authority that women have developed in these societies, and that were extended to the colonial society, require further studies.
\end{abstract}

Keywords: Female Rulers, Gender, Politics, History, East Africa. 
Durante longo tempo, a história de África e das suas instituições políticas foi analisada descrevendo os homens como únicos actores e destacando como excepcionais os casos em que mulheres exerceram alguma forma de autoridade pública. Como argumentou Buijs, muita literatura "sobre África gasta um tempo considerável detalhando o papel das mulheres como objectos de troca, mas existe relativamente pouco sobre as mulheres como actores sociais de direito próprio" (Buijs, 2002:70-71). ${ }^{1}$

Nas últimas décadas, a investigação académica tem dedicado um espaço crescente às mulheres enquanto actores sociais e políticos, enfatizando nomeadamente a sua agência no período pré-colonial. Esses estudos têm incidido, particularmente, sobre as sociedades da África Ocidental, iluminando a existência de mulheres em lugares de autoridade pública e, em particular, o papel daquelas que a literatura convencionou chamar rainhasmães. Tal investigação mostrou como as mulheres das linhagens governantes, o equivalente às famílias reais e aristocráticas na Europa, longe de ocuparem apenas posições cerimoniais, detinham uma considerável autoridade política, exercendo diversos cargos, individualmente ou em conselhos. Em algumas dessas sociedades, existiam mesmo práticas de co-governação, que previam a existência de cargos femininos a par dos masculinos (v.g. Aidoo, 1981:65-77; Farrar, 1997; Kaplan, 1997; Oyěwùmí, 1997; Bay, 1998; Hanson, 2002; Wright, 2004:418-421; Semley, 2011).

As sociedades da África Oriental não têm estado arredadas desse debate, mas apenas mais recentemente os académicos tentam compreender a participação das mulheres nas instituições políticas nessa parte do continente. Em 1995, John Iliffe (1997:115116) concluía mesmo que as mulheres na África Oriental tinham "um estatuto mais baixo do que na África Ocidental". Nos últimos anos, algumas investigações trouxeram essas mulheres para o centro da análise histórica, buscando entender os seus papéis políticos, por vezes, em conexão com outros papéis sociais, no

\footnotetext{
1 Todas as traduções de língua estrangeira são da responsabilidade da autora.
} 
período anterior à colonização europeia, como no caso dos gandas, vendas e zulus (Hanretta, 1998; Buijs, 2002; Hanson, 2002; Saidi, 2010; Stephens, 2013).

Neste texto, procuro fazer uma primeira abordagem às formas de poder político exercido pelas mulheres no sudeste da África Oriental, considerando as sociedades com as quais os portugueses interagiram entre os séculos XVI e XVIII e sobre as quais produziram registos. Nos anos de 1970 e 1980, investigações realizadas sobre os estados pré-coloniais desta área expuseram papéis das mulheres nas instituições políticas dessas sociedades, mas não exploraram a relevância dessa participação, que apenas ultimamente atraiu a atenção dos académicos (Zimba, 2003, Zimba, 2005; Pabiou-Duchamp, 2005; Levin, 2013; Rosário, 2015). ${ }^{2}$ Ao centrar-me nas formas mais institucionalizadas de poder político, não ignoro que, nestas sociedades, as mulheres, sobretudo as mais velhas, desempenhavam outras formas de autoridade ou de influência reconhecidas a nível familiar e social, mas cuja prática não cabe analisar no âmbito deste artigo.

As sociedades a que se reporta este texto localizaram-se no litoral da Ilha de Moçambique, a capital da colónia portuguesa estabelecida no Sudeste da África Oriental a partir do século XVI, e em volta dos Rios de Sena, que constituía uma capitania dependente do governo colonial de Moçambique. Rios de Sena era uma designação política e geograficamente fluida para o

2 Como está amplamente estabelecido na literatura, os estados pré-coloniais em África caracterizam-se mais pelo controlo das pessoas do que do território. Como argumenta Herbst (2000:37), "[a]ssumir que os estados e os sistemas de estados não existiram em África simplesmente porque não foi seguido o modelo europeu demonstra, no mínimo, uma falta de imaginação e, mais importante, uma concepção bastante estreita de como o poder pode ser organizado. Assimilar os estados com um firme controlo territorial é interpretar mal mesmo muita da própria história da Europa. [...] De facto, pode discernir-se a existência de estados e o sistema de estados na África pré-colonial se se descartar os preconceitos baseados na história recente da Europa. Os estados africanos transmitiam a autoridade, tinham noções firmes do que significava a consolidação do poder e desenvolviam convenções para as relações entre estados". 
território em torno do rio Zambeze, ao qual os portugueses acediam, consoante o período, a partir de Sofala, a sul, e de Quelimane, no delta do rio, compreendendo regiões correspondentes hoje, para além de Moçambique, a territórios do Zimbabué, Zâmbia e Mali. Estas sociedades, como outras em África, estavam organizadas na base de grupos de parentesco, em linhagens, que não eram estáveis, antes tinham configurações plásticas pela necessidade de absorver novos grupos ou indivíduos. Porém, o Zambeze marcava, grosso modo, uma fronteira entre as sociedades em que o parentesco era estabelecido predominantemente pela linha patrilinear, a sul do rio, e pelos laços matrilineares, que dominavam a norte. ${ }^{3} \mathrm{Em}$ todas essas sociedades, os protagonistas do poder político eram, comummente, masculinos, mas as mulheres ocuparam cargos tanto na administração central dos estados aí constituídos, quanto ao nível das chefaturas regionais e locais. Importa, igualmente, notar que mesmo em situação de forte interacção colonial como era o caso do vale do Zambeze, as mulheres detentoras de concessões fundiárias da coroa portuguesa - os prazos detiveram jurisdição sobre territórios (Isaacman, 1972; Newitt, 1973; Newitt 1995:217-242; Capela, 1995; Rodrigues, 2013).

Neste texto, procuro evidenciar como as mulheres das linhagens governantes na África Oriental, mais especificamente no território de Moçambique e para lá das suas fronteiras actuais, detiveram funções políticas proeminentes. É certo que o seu papel de autoridade pública, por um lado, estava embebido na dinâmica de múltiplas identidades, nas relações de parentesco e em visões cosmológicas próprias e, por outro, se definia também em relação ao das figuras masculinas. Mas, nesta abordagem inicial importame, sobretudo, mostrar que, em maior ou menor grau, elas ocuparam posições de autoridade pública em todas essas

${ }^{3}$ Esta divisão, necessariamente simplificada neste contexto, não significa que não existissem, tanto a sul como a norte do rio, formas de parentesco bilateral com arranjos variados. Sobre as sociedades organizadas em linhagens patrilineares e matrilineares, ver, por exemplo, Vansina, 1990; para uma crítica, v.g. MacGaffey, 2005; 2013. 
sociedades. A literatura tem categorizado os papéis dessas mulheres como "rainhas-mães", "irmãs dos pais", "irmãs rituais" $e$, em alguns casos, como chefes. Em todas essas situações, como argumenta Buijs (2002), a melhor expressão para as identificar será, provavelmente, "mulheres governantes". Essas formas de autoridade passaram pelo desempenho de cargos políticos, mas também, no caso das sociedades a norte do Zambeze, pelo exercício de funções religiosas que se relacionavam com toda a sociedade. Nesta análise, privilegio a documentação produzida pelo arquivo colonial, como memórias descritivas e a correspondência entre as autoridades portuguesas em Moçambique e entre estas $e$ as chefias africanas, usando, igualmente, os estudos que se baseiam nessas fontes e na tradição oral. 


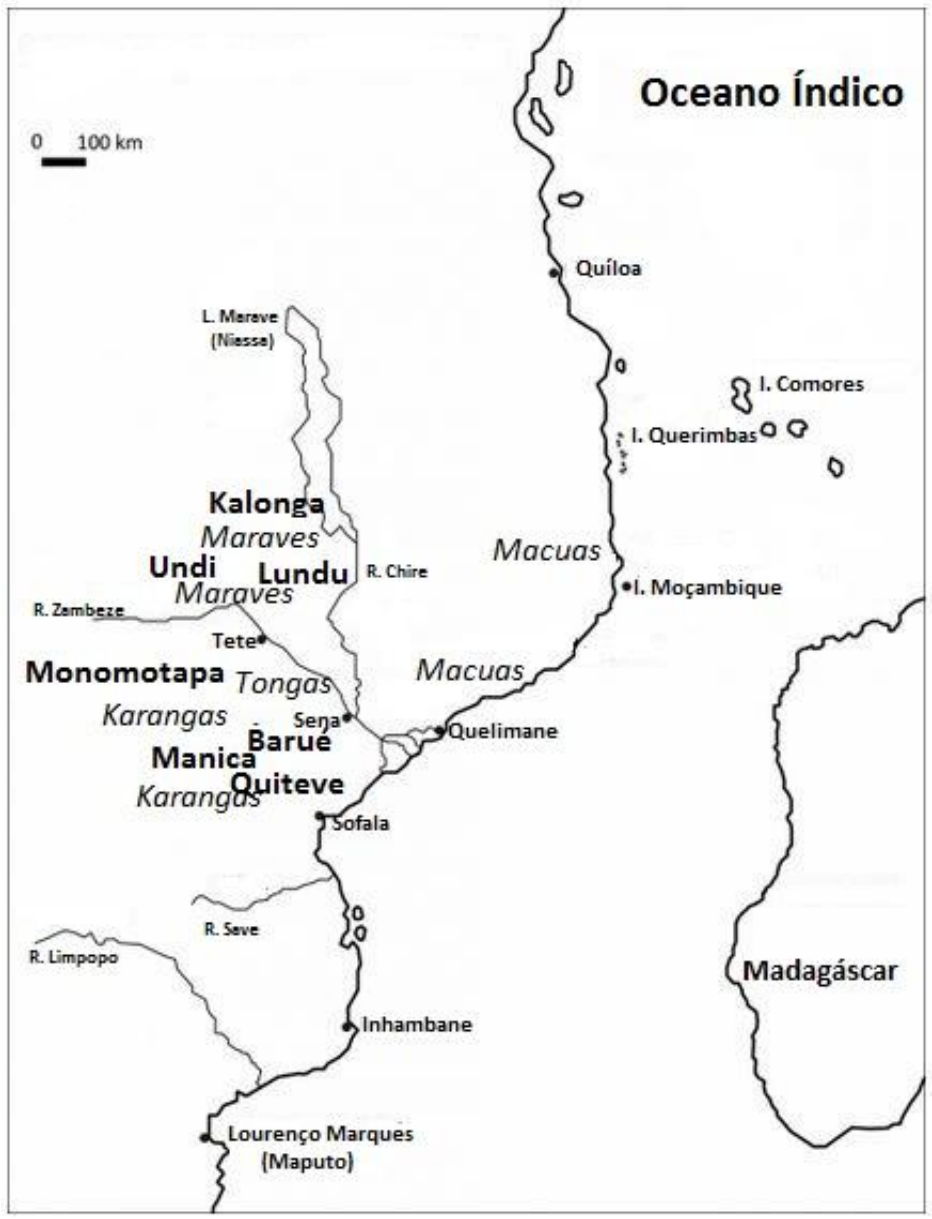

O Sudeste da África Oriental, séculos XV-XVIII Elaborado pela autora. 
1. Mulheres e organização política nas sociedades de descendência patrilinear: os estados karangas

Na região a sul do rio Zambeze, constituíram-se diversos estados karangas. Entre eles, o Monomotapa, ou Mukaranga, foi celebrizado pelas fontes portuguesas como um "império", com tutela sobre diversos outros estados que acabaram por se autonomizar, como foram os casos de Manica, Quiteve, Barué e Danda (v.g. Beach, 1980; 1994; Mudenge, 1988; Pikirayi, 2001). Conquanto, em todos estes estados, os principais detentores do poder fossem homens, as mulheres ocuparam posições relevantes na estrutura política.

As fontes portuguesas reportam a existência de inúmeras mulheres do mutapa, o soberano do Monomotapa, sendo umas parentes próximas e outras membros de linhagens distintas, o que fazia parte das estratégias para estabelecer alianças. $\mathrm{O}$ cronista do Estado da Índia, António Bocarro, que, na década de 1630, detalhou a estrutura política do Monomotapa, indicou que o mutapa tinha várias "mulheres grandes" ou "como rainhas" (Bocarro, 1876:539 [c.1635]). Como destacou Pabiou-Duchamp (2005:101-104), essas mulheres não eram necessariamente esposas do soberano karanga. Importa, igualmente, notar que, como noutras sociedades africanas em que o parentesco era usado classificatoriamente para traduzir relações de dependência política, a denominação "mulheres" tinha para os karangas um significado político. Como assinala Wyatt MacGaffey, em muitas partes de África, o par marido-mulher era um template para certas relações, independentemente do género. ${ }^{4}$ No Monomotapa, a denominação "mulheres" aplicava-se também a chefes que administravam territórios, com os quais o mutapa estabelecia pactos, assim como aos seus aliados estrangeiros, como era o caso dos portugueses.

\footnotetext{
${ }^{4}$ Nesse sentido, todos os termos de parentesco devem ser olhados mais como "fiç̧ões legais" do que como laços biológicos (MacGaffey, 2013:276. Ver também MacGaffey, 2005), ou, ainda, ser entendidos "metaforicamente" (Kopytoff 1987:50; MacGaffey, 2005:195).
} 
Isso foi notado, por exemplo, por Frei João dos Santos quando contactou os karangas no final do século XVI, tendo sido interpretado por ele como uma deferência em relação aos portugueses (Santos, 1999:135 [1609] ; ver também Beach, 1994:97). ${ }^{5}$ Esse uso dos termos de parentesco para classificar diversas relações de aliança pode complicar a análise das fontes portuguesas, implicando, necessariamente, a atenção ao contexto de produção e circulação dessas notícias. No entanto, os portugueses não possuíam apenas uma informação vaga da corte do mutapa. Desde o século XVI, eles frequentavam essa capital e, sobretudo, a partir das primeiras décadas da centúria seguinte, foram construindo um conhecimento notório sobre as estruturas e actores políticos karangas. Conforme o cronista Bocarro, todas essas mulheres governavam terras e vassalos, dispondo da sua própria corte:

Todas estas são mulheres grandes do rei, e tem casas $e$ estados sobre si, e com todos os oficiaes que o rei tem, e muitas terras e vassalos, e algumas destas tem reinos apoticados a suas casas; e em morrendo alguma d'estas, logo lhe sucede na mesma casa e estado e nome outra mulher que o rei põe em seu logar. Estas todas tem jurisdicção sobre seus vassalos (Bocarro, 1876:539 [c.1635]).

Assim, essas mulheres exerciam jurisdição sobre determinado território e os seus habitantes, e dispunham de um conjunto de oficiais que replicava os cargos do aparelho administrativo do mutapa. A posse de territórios garantia a essas governantes, como noutras partes de África (v.g. Hanson, 2002:221), recursos materiais autónomos, tal como indivíduos que podiam mobilizar. Os nomes indicados pelo cronista reportam-se a

\footnotetext{
${ }^{5}$ Frei João dos Santos recolheu as informações sobre os karangas durante a sua estada em Sofala, entre 1586 e 1590, e em Tete, em 1591, tendo regressado posteriormente ao vale do Zambeze. Para uma biografia de Frei João dos Santos, ver a introdução de Manuel Lobato à mais recente edição de Etiópia Oriental (Santos, 1999:7-10 [1609]).
} 
cargos que elas exerciam, donde terem de ser substituídas quando morriam, de modo a haver quem "que herde aquella casa $e$ estado" (Bocarro, 1876:539 [c.1635]). Como noutras sociedades de África, o poder parece ter-se distribuído, ainda que desigualmente, entre figuras masculinas e femininas.

Mas quem eram essas mulheres? Bocarro indica nove nomes, dos quais os mais importantes eram Mazarira (mazvarira), Inhahanda (nehanda) Nabuiza (nyazvidza?) (Bocarro, 1876:539 [c.1635]). Antes, ele já mencionara como primeira "mulher grande" Inhacanemba, a chefe do importante território de Mungussy (Bocarro, 1876:537 [c.1635]), para, na série de nove mulheres, anunciar que a

principal se chama Mazarira, que sempre é das irmãs do rei, a quem os portuguezes mandam por isso os seus presentes. E nenhum embaixador manda o Manamotapa aos portuguezes, que vá sem um criado da Mazarira (Bocarro, 1876:539 [c.1635]).

Esta informação retomava a de Frei João dos Santos, que, no final do século XVI, reconhecia mazvarira como a principal mulher do mutapa e defensora dos interesses dos portugueses no zimbabwe, ou seja, na corte do mutapa. Aqueles, sempre que pagavam o tributo (kuruva) ao mutapa, enviavam presentes a essa mulher (Santos, 1999:220,223 [1609]). Bocarro informa, de seguida, que a segunda mulher é "Inhahanda, a qual falla pelos mouros", como os portugueses designavam os mercadores muçulmanos ou suaílis que dominavam o comércio com a costa antes de eles próprios se tornarem os principais intermediários dessas rotas, enquanto a terceira era nyazvidza, "a sua verdadeira mulher, porque só esta mora dentro dos paços com o rei", i.e., no zimbabwe, onde tinha "seu serviço e officiaes como o rei" (Bocarro, 1876:539 [c.1635]). A descrição de Bocarro, apesar de aludir a várias mulheres, acaba por valorizar apenas uma como a sua "verdadeira mulher", ou seja, a que coabitava com ele, de acordo com o modelo católico e tridentino de casamento. No entanto, a sociedade karanga era 
poligâmica e de residência virilocal, como outras descrições acentuam (Mudenge, 1988:9-12; Macgonagle, 2007:57-68).

Assim, as duas primeiras mulheres, que deveriam ser escolhidas entre as irmãs, eventualmente, classificatórias, do mutapa ${ }^{6}$, exerciam funções diplomáticas na sua corte. Esses autores declaram que a principal das duas era mazvarira, a interlocutora dos mercadores portugueses. Nehanda, i.e., a governante de Handa (Mudenge, 1988:105), tinha, provavelmente, a primazia numa fase anterior, $e$ voltou a ser representada como a mulher mais importante na segunda metade de Setecentos. O nome de ambas está associado aos mitos fundadores do Monomotapa (Pacheco, 1883:148 [1864]). Mudenge (1988:106) sustenta que mazvarira era o título da irmã do primeiro mutapa, Mutota, portanto, irmã do pai de nehanda, esposa e irmã do segundo mutapa, Matope, com uma posição inferior à dela. A informação dos escritores portugueses sobre a primazia de mazvarira, nas primeiras décadas do século XVII, não significa necessariamente um viés associado à auto-representação da sua própria relevância na corte do mutapa. De facto, com o crescimento da influência dos portugueses na Mukaranga, o cargo de mazvarira parece ter adquirido importância. $\mathrm{Na}$ década de 1640, o mutapa Mavhura reclamava em carta ao rei de Portugal de quem, por um tratado celebrado em 1629, se tornara vassalo do abandono em que as forças portuguesas o deixavam perante a contestação dos seus súbditos. E, sentenciando que "não tenho ja oje de quem me fie mais que de huma molher que he Mauzarira", avisava os portugueses para confiarem apenas nela. ${ }^{7}$ Esta carta sugere que mazvarira, para além de manter a sua relevância política, continuava a ser a principal mediadora entre o mutapa e os portugueses.

${ }^{6}$ Para uma discussão sobre se estas parentes eram esposas rituais ou reais e sobre o incesto real, ver Mudenge (1988:104-110); Beach (1994:96-98). Sobre essas mulheres, ver, também, Pabiou-Duchamp (2005); Levin (2013).

7 Carta do mutapa Mavhura para o rei D. João IV, 4.03.1643, Arquivo Histórico Ultramarino (AHU), Moçambique (Moç.), cx.2, doc.31. 
É possível que inhacanemba, que aparece fora da série de nove "mulheres grandes" do mutapa, identificasse, no quadro da linguagem política do parentesco, uma importante chefe, já que o seu território, Mungussy, é reconhecido como o principal "reino" vassalo do Monomotapa. Ou que correspondesse à posição da anterior "imperatriz" ou de mãe do mutapa, semelhante à "rainhamãe" existente noutros estados africanos (v.g. Hanson, 2002). De qualquer modo, o papel da mãe do mutapa foi salientado nas descrições da visita, em 1561, do jesuíta D. Gonçalo da Silveira ao zimbabwe, onde ele baptizou, conjuntamente, o soberano e a sua chamada mãe, para além de outros elementos da sua corte. Quando a acção de Silveira passou a ser disputada, a mãe do mutapa deslocou-se ao zimbabwe para se associar ao conselho que decidiu a sua morte. ${ }^{8} \mathrm{O}$ mercador português António Caiado contou como ela, quando retornou à sua própria casa, "deixava ya concertado com o filho que a noyte o matassem". ${ }^{9}$ O destaque que as narrativas desse encontro dão à mãe do mutapa indicia que, nessa altura, este cargo tinha um papel de relevo no aconselhamento do soberano $e$, mesmo, na sua defesa numa posição de vulnerabilidade.

A partir da década de 1630, quando os portugueses se tornaram mais assíduos no Monomotapa, as notícias sobre a forma como as relações de género eram incorporadas na estrutura política do Monomotapa tornaram-se mais abreviadas. E passaram a valorizar a quantidade de mulheres do mutapa, destacando apenas "huma maior de todas, a qual as mais respeitam, e obedecem" (Conceição, 1867:66 [1696]), sem, contudo, a identificar. Já em Setecentos, o papel de nehanda passou a ser realçado como o de primeira mulher: "A primeira mulher do Imperador hé Prinçeza ainda sendo sua própria irmã, ou parenta; a esta se chama Neanda, e logra todos os privilégios e

8 “Carta do padre jesuíta Luís Fróis", 15.12.1561. In: Documentos, 1975:VIII,3458.

9 "Carta de António Caiado para um amigo", 1561. In: Documentos, 1975:VIII,2-8. 
foros do Imperador seu marido" (Miranda, 1955:312 [c.1766]). Uma outra relação, já do final do século, alude, ainda, às muitas mulheres do mutapa, todas, como o próprio estado, designadas "Mucarangas [vakaranga, i.e., mulheres], com este, ou aquelle titulo", o que sugere que existia uma diferenciação entre essas mulheres. Mas, o autor apresenta a "imperatriz" como destituída de qualquer autoridade. ${ }^{10}$

Nesta altura, o mutapa perdera grande parte do território que governava ${ }^{11}$ e é possível que aí estivessem incluídas terras em que essas mulheres exerciam jurisdição. Esse, pelo menos, era o caso de nehanda, cujo território, Handa, se localizava no Dande, sobre o qual o mutapa já não tinha soberania desde meados do século XVIII (Mudenge, 1988:108). Apesar do retrato produzido pelos autores portugueses, as informações fornecidas sobre o processo de sucessão dos mutapa indicam que essas mulheres conservavam algum poder. Conforme o mesmo autor, a "imperatriz", mulher do soberano defunto, exercia funções de guarda da sepultura do mutapa:

pegão da imperatrix, $e$ a poem naquelle lugar, com mais quatro ou sinco mulheres, $e$ alguns homes para aly estarem por toda a vida de guarda ao dito imperador defunto, e este lugar de sepultura se chama massanza, a quem os imperadores reinantes tem grande respeito, e lhe concede varios privilegios mas elles não podem entrar nella, e pelo tempo se vay povoando este lugar, e tem juntamente seus grandes; e quando morre a tal imperatrix tem obrigaçam os

10 "Descripção do Imperio Moanamotapa", ant.2.03.1794, AHU, Moç., cx.66, doc.55.

${ }^{11}$ Depois de, em 1629, ter perdido territórios para os portugueses, ao longo do século XVIII, a autoridade do mutapa estendia-se a um espaço cada vez mais reduzido, até que, na década de 1760, o Monomotapa se fragmentou em Chidima, que os portugueses continuaram a chamar Mukaranga, e Dande (Beach, 1980; Mudenge, 1988; Pikirayi, 2001). 
ditos Imperadores dar o titulo a outra que deve logo por na dita massanza. ${ }^{12}$

Assim, nesse espaço, constituía-se uma corte, com os "seus grandes", portanto, com uma forma de governo, com privilégios reconhecidos pelos mutapa. $\mathrm{O}$ soberano tinha de designar uma nova "imperatriz" quando a anterior falecia, o que significa que esse título correspondia a um cargo na estrutura do estado. As mulheres também jogavam um papel no processo de escolha dos mutapa. De facto, a sucessão nos estados karangas baseava-se na adelfia, devendo o próximo mutapa ser apurado, pela linha patrilinear, entre os irmãos do anterior soberano ou na geração seguinte. Porém, essas regras eram apenas prescritivas, pelo que os demorados processos de sucessão resultavam de intensas contendas pelo poder e da constituição de alianças (Mudenge, 1988:81-82). Conforme o mesmo relato, à morte do soberano, seguia-se um período de lutas, havendo "levantamentos dos pretendentes e os vassalos seguirem huns a este, e outros aquelle filho do Moanamotapa, e o mesmo observão, as mulheres". ${ }^{13}$ Nessa narrativa, a representação masculina e europeia da organização do poder no Monomotapa parece desvalorizar, ou mesmo apagar, um papel das mulheres que acaba por emergir: elas também faziam coligações políticas e intervinham na escolha dos governantes.

Os dados disponíveis não permitem avançar com alguma segurança sobre as razões do menor protagonismo político das mulheres governantes nestas memórias portuguesas. Isso pode dever-se a uma depreciação do seu papel por uma ideologia patriarcal do poder, que começou por reportar as diferenças em relação ao seu próprio contexto político para, posteriormente, se acomodar a elas. Ou pode relacionar-se com transformações das

12 "Descripção do Imperio Moanamotapa", ant.2.03.1794, AHU, Moç., cx.66, doc.55. Ver também Pacheco (1883:155 [1864]).

13 "Descripção do Imperio Moanamotapa", ant.2.03.1794, AHU, Moç., cx.66, doc.55. 
estruturas políticas do Monomotapa, em função de dinâmicas internas, como a redução do território sob autoridade dos mutapa, ou da interacção com os portugueses, já que estes, diferentemente do que faziam nos primeiros contactos com os karangas, tendiam a negociar apenas com os detentores masculinos dos cargos.

As fontes portuguesas indicam, porém, que, durante este período, ocorreram alterações no papel que as mulheres desempenhavam nas relações diplomáticas do estado Monomotapa. De intermediárias dos mercadores estrangeiros no zimbabwe, as próprias mulheres passaram a integrar as delegações enviadas aos portugueses. A permuta de embaixadas entre karangas e portugueses ocorria desde os primeiros contactos, segundo um ritmo próprio. $\mathrm{E}$, depois do tratado de vassalagem de 1629 , os portugueses impuseram uma representação permanente no zimbabwe, onde tinham um capitão e um vigário, com algumas intermitências, até meados do século XVIII. ${ }^{14} \mathrm{Na}$ sequência da fragmentação política do Monomotapa e da maior disputa pelos bens importados, os mutapa e outros chefes karangas passaram a enviar sucessivas embaixadas a Tete - desde 1767, a capital dos Rios de Sena. Nessas enviaturas, notava-se o acréscimo do número de embaixadores, que passaram a incluir uma mulher (Mudenge, 1988:143-153; Rodrigues, 2004).

Designadas na documentação portuguesa como "mucarangas", as mulheres embaixadoras eram parentes do mutapa, sendo identificadas como suas esposas ou filhas. Num curto período, de Dezembro de 1780 a Abril de 1781, o mutapa Ganyambadzi enviou cinco delegações a Tete, destinadas a negociar importantes questões como o estabelecimento da paz e o pagamento de tributos pelos portugueses, todas elas envolvendo, também, mulheres. Na primeira delegação estava Vamuturo; a segunda, repetida dias depois, incluía Mavu, identificada como

\footnotetext{
${ }^{14}$ Note-se que os portugueses foram expulsos do zimbabwe no final do século XVII, pelo changamira de Butua. Na primeira metade de Setecentos, consoante a conjuntura política, ainda mantiveram durante alguns períodos essa representação.
} 
filha do mutapa; na quarta, apareceu Tondato, enquanto na última participava a Tondo. A narrativa destas embaixadas mostra que várias mulheres, designadas pelos seus próprios nomes, desempenhavam funções diplomáticas. O estatuto público dessas embaixadoras, enquanto representantes do mutapa, era reconhecido pelas autoridades portuguesas, que, tudo indica, lhes concediam uma posição superior à do restante dos embaixadores, provavelmente, pelas relações de parentesco que as ligavam ao soberano. Elas eram recebidas com uma dignidade especial, sendo-lhes fornecidos, apenas a elas, uma alcatifa e um coxim para se sentarem, como é descrito em relação à mukaranga Vamuturo. ${ }^{15}$ Delegações semelhantes continuaram a chegar a Tete, como a enviada, em 1802, pelo mutapa Changara, que incluía a "imperatriz". ${ }^{16}$

Estas missões reflectem a relevância das mulheres embaixadoras na cultura política karanga, ao mesmo tempo que denotam uma transformação do seu papel. As suas funções diplomáticas anteriores tinham-se restringido ao zimbabwe e, tudo indica, elas agiam em nome próprio ou, pelo menos, com grande autonomia. No final de Setecentos, a integração nas missões diplomáticas implicava para essas mulheres viajar durante dias até às feiras portuguesas ou, mais frequentemente, até Tete. Tais deslocações conferiam visibilidade a essas embaixadoras tanto no espaço karanga, quanto no espaço colonial. O seu papel sugere, ainda, que o mutapa queria ter um controlo apertado sobre as negociações, pelo que escolhia essas emissárias entre as parentes próximas. Mantendo um papel de intermediárias entre a elite política karanga e os estrangeiros, estas mulheres parece terem tido menor autonomia do que as suas antecessoras no zimbabwe.

O estado do Quiteve, ou Teve, governado pelos sachiteve, está documentado pelas fontes portuguesas ao longo do tempo, permitindo perceber como a estrutura política incorporava as

\footnotetext{
${ }^{15}$ Termo da embaixada ao mutapa, 18.12.1780, AHU, Moç., cx.34, doc.84.

${ }^{16}$ Carta de José Luís de Meneses para Jerónimo Pereira, 26.06.1802, AHU, Moç., cx.93, doc.74.
} 
mulheres governantes (Mtetwa, 1984; ver, também, Macgonagle, 2007; Roque, 2012). Reportando-se ao final do século XVI, Frei João dos Santos referiu a existência de várias mulheres do sachiteve, das quais duas eram suas "mulheres grandes, como rainhas", enquanto as restantes eram "mancebas", que podiam ser recrutadas entre as suas irmãs (Santos, 1999:87 [1609]). Na verdade, a estrutura do estado implicava a existência de duas "rainhas", posteriormente identificadas como nengomanye $e$ namsunga, aquela com precedência sobre esta (V.g. Resposta, 1966:20 [c.1794]). Em 1835, Sebastião Xavier Botelho, antigo governador-geral de Moçambique (1825-1829), apoiado num informador local, João Julião da Silva, também ele autor de narrativas sobre o Quiteve, descrevia-as deste modo:

Huma e outra rainha, alem de aposentos separados tem casa própria com seu apanágio, que consiste em mui rendosas terras, e com séquito de grandes e magnates, a quem pagão, e conferem os cargos do palácio. Estes grandes e magnates como falesça qualquer delas, ajuntão-se, conferem, $e$ escolhem outra a seu alvedrio, dentro da familia real (Botelho, 1835:154).

Tal como no Monomotapa, essas designações identificavam cargos ocupados por mulheres que governavam os seus próprios territórios, em Hanganhe, a três dias da corte do sachiteve, localizada em Ussema (Ferrão, 1833:413 [a.1823]). Aí tinham os seus próprios zimbabwe com o seu corpo de oficiais, cabendo-lhes aconselhar regularmente os sachiteve sobre assuntos do governo (Botelho, 1835:154-156). Além destas, outras cinco mulheres são nomeadas e descritas nas fontes portuguesas como governantes de territórios, dos quais saíam apenas quando chamadas pelas "rainhas" (Silva, 1998:68-72 [1844]; Botelho, 1835:154-155. Ver, também, Mtetwa, 1984:268-269).

O papel destas mulheres era fundamental na sucessão dos sachiteve, um processo que começava com as cerimónias fúnebres do anterior governante, presididas por alguém designado por elas (Ferrão, 1833:418 [a.1823]; Botelho, 1835:165. Ver, também, 
Macgonagle, 2007:63-65). O mais notável é que eram elas, depois de ouvidos os principais chefes, a escolher o novo suserano. Como no Monomotapa, o processo de eleição era lento, envolvendo, frequentemente, guerras entre vários contendedores, que disputavam o apoio dessas mulheres com o envio de presentes (Botelho, 1835:155-156). De acordo com Frei João dos Santos:

é lei que nenhum príncipe entre nas tais casas [reais] em que elas [mulheres] estão sem licença, nem tome posse do reino sem sua vontade, e o que por força entrar, e tomar posse, perca o direito que tem na sucessão do reino, $e$ ninguém poderá contradizer ao que as mulheres nesta eleição fizerem (Santos, 1999:91 [1609]).

Estas "rainhas" assumiam, portanto, um papel institucional na escolha dos soberanos, diversamente do que ocorria no Monomotapa, onde as mulheres poderiam influenciar o processo de sucessão. Eram, ainda, nengomanye e namsunga a presidir à cerimónia de entronização dos soberanos. Elas regavam o sachiteve com pombe, uma bebida de cereais fermentados usada em vários rituais, enquanto recapitulavam histórias de bravura dos antepassados. Feito isso, tate, o principal oficial de nengomanye, banhava o novo chefe numa lagoa. De seguida, as mulheres vestiam-no com tecidos ricos fornecidos pelos portugueses $e$ entregavam-lhe as insígnias reais. Depois de um discurso de tate, o sachiteve subia ao quite (trono) e era aclamado, primeiro, por tate, depois, pelas "rainhas" e, finalmente, pelos chefes do Quiteve. As funções executadas por nengomanye e namsunga neste cerimonial evidenciam o seu papel na coesão e na continuidade do estado. Elas garantiam a identidade do grupo, actualizada pelas histórias sobre os antepassados, e eram, conjuntamente, as guardiãs dos símbolos do poder, as insígnias sem as quais nenhum sachiteve era reconhecido (Botelho, 1835:155-160; Silva, 1998:76-78,129 [1844]; ver, também, Mtetwa, 1984:266).

Finalmente, diferentemente do Monomotapa, onde o nevinga tinha esse papel, eram nengomanye e namsunga a dirigir o estado nos interregnos, assistidas pelo conselho das restantes cinco 
mulheres e, provavelmente, por outras chefias importantes (Botelho, 1835:155; Silva 1998:69-72 [1844]). Conquanto essa fosse a prática habitual, à morte do sachiteve Tica, em 1803, sucedeu-se um longo interregno até c. 1830 (Mtetwa, 1984:267-280). Durante este período, os portugueses negociavam com nengomanye e namsunga, tentando reabrir a antiga feira do ouro de Bandire. As notícias sobre essas embaixadas evidenciam como essas mulheres tomavam decisões em conselho, mas era delas a última palavra. ${ }^{17}$

As mulheres não tiveram, provavelmente, o mesmo protagonismo político no estado de Manica. A sua visibilidade é escassa na documentação portuguesa, conquanto as fontes orais usadas por H. Bhila (1982) lhes concedam algum espaço. Tal como os outros governantes karangas, o chikanga dispunha de um vasto número de mulheres, que, no final do século XVIII, seriam cerca de sessenta, entre as da sua própria linhagem $e$ as filhas de chefes com quem estabelecia alianças. Quatro tinham "o titulo de rainhas, das quaes Nhabinga, Nemanhica são as primeiras". ${ }^{18}$ Não se sabe que participação estas mulheres tinham no governo do estado, mas é possível que assegurassem aí alguma função. Cerca de 1795, quando se disputava a sucessão de chikanga Gowera, o governador dos Rios de Sena ordenou que o binzo, uma contribuição anual que permitia aos portugueses fazerem comércio em Manica, fosse entregue às mulheres do falecido. ${ }^{19}$ Conquanto os interregnos fossem assegurados, também neste estado, pelo nevangi, tudo indica que essas mulheres desempenhavam algum papel nesse período. Bhila $(1982: 16,20)$ relaciona a intensa conflitualidade prevalecente no século XVIII com a actividade das esposas juniores dos chikanga, que se aliavam a candidatos ao trono para eliminar os soberanos. Ou seja, mesmo que o papel das mulheres do chikanga

${ }^{17}$ Carta de Francisco de Paula Albuquerque para o secretário de estado, 7.09.1806, AHU, Moç., cx.116, doc.97; Silva (1844) 1998:52-54,72-75. Ver, também, Mtetwa (1984:278).

18 "Discripção Corografica do Reino da Manica seus Custumes, e Leis", AHU, Moç., cx.34, doc.91.

${ }^{19}$ Carta de João de Sousa e Brito para Francisco Henriques Ferrão, c.1795, AHU, Moç., cx.72, doc.98. 
na escolha dos governantes não tivesse um carácter normativo, como no Quiteve, ele parece ter sido, pelo menos, contingencial.

Em vez das mulheres do chikanga, Bhila, baseando-se na tradição oral, valoriza o cargo de semukadzi, a sua irmã ou mulher sénior da linhagem, um papel político existente, igualmente, entre outros povos da África Oriental, como os vendas (Buijs, 2002). Na verdade, a posição de semukadzi existia ao nível de todas as familias dos vários estados karangas, sendo reconhecida à tia mais velha uma grande autoridade espiritual (Silva, 1998:69 [1844]). Os deveres de semukadzi, que também administrava um território, relativamente à constituição política de Manica consistiam em aconselhar o chikanga, apenas em algumas situações como a guerra, a fome ou epidemias. Mais relevante, tal como as mulheres governantes do Quiteve, semukadzi cumpria funções institucionais na sucessão dos soberanos. Era ela, que, enquanto médium através do qual se revelava Nyamandoto, o espírito ancestral protector de Manica, designava o novo chikanga, conquanto esta nomeação, também aqui, fosse frequentemente decidida pelas armas. No final do século XVII, quando o changamira rozvi estendeu a sua tutela a Manica, o papel de semukadzi declinou, conquanto ela continuasse a participar nas cerimónias de investidura (Bhila, 1982:14-21). Tudo indica que a posição de semukadzi se replicava ao nível de outras linhagens. Em 1798, quando a sua liderança estava a ser contestada, o soberano chikanga queixou-se das boas relações que um dos mercadores da feira de Manica tinha com a irmã do seu rival, Inhagote, oferecendo-lhe presentes. ${ }^{20}$

Além desses papéis na administração central do estado, as mulheres também assumiam chefias locais. Durante o século XVIII, os soberanos passaram a indicar familiares suas como chefes de dunhu, i.e., distritos, dando origem à instituição das mulheres governantes conhecidas por washe. Bhila (1982:22-23) considera que esta solução visava contrabalançar as tendências secessionistas dos filhos do soberano, já que um exército não seguiria uma mulher.

\footnotetext{
${ }^{20}$ Carta de Francisco Henriques Ferrão para Francisco de Lacerda e Almeida, 2.11.1798, AHU, Moç., cx.81, doc.89.
} 
Era, provavelmente, a uma destas washe que se referia o naturalista baiano Manuel Galvão da Silva no diário da viagem que, em 1788, fez até à feira de Manica. Ele relatou que "hoje tem ali o Chicanga posto huma das suas Mulheres, que vive perto da feira, e se diz Princeza della, e cobra por isso hua pessa de fato" (Silva, 1998:327 [1790]). Essa mulher governante recebia, assim, um imposto - uma peça de tecido - de todos os mercadores, detendo, igualmente, jurisdição sobre as questões judiciais ocorridas na feira, como Galvão da Silva experimentou na pele (Silva, 1998:330 [1790]).

Em suma, nas sociedades karangas do sul do Zambeze, as mulheres das linhagens governantes tinham uma participação importante, conquanto variável, nas instituições políticas. Através de vários mecanismos, sobretudo no aconselhamento dos soberanos $e$ no processo de sucessão, elas intervinham nas decisões políticas $e$ asseguravam a preservação do grupo social e da sua identidade. Além disso, algumas mulheres administravam territórios sobre os quais exerciam jurisdição e onde recolhiam tributos. Tudo indica que essa agência política das mulheres era superior à existente noutras sociedades de parentesco patrilinear do Sul de Moçambique, onde, porém, o poder das mulheres a nível familiar e social, em particular das mais velhas, era significativo (v.g. Junod, 1996).

2. Mulheres e organização política nas sociedades de descendência matrilinear: maraves e macuas

Nas sociedades a norte do Zambeze, o poder das mulheres no espaço social parece ter sido maior e relacionar-se com a descendência matrilinear e a residência uxorilocal. A maior parte das chefias eram masculina, escolhidas entre os filhos das irmãs dos soberanos, mas as mulheres conseguiam importantes papéis sociais, políticos e religiosos. No território a norte do rio, encontravam-se dois grandes grupos de povos, que integravam diversos sub-grupos linguísticos e culturais: os maraves numa área que, grosso modo, se fixou entre os rios Aruângua e Chire; os macuas, em toda zona próxima da costa, destacando-se aí, assim 
como nas ilhas vizinhas, as comunidades suailis, com forte influência islâmica.

Os maraves, em migrações sucessivas, que remontavam pelo menos ao século XIV, dominaram progressivamente as populações pré-existentes e fizeram incursões até ao litoral, eventualmente estabelecendo algumas chefaturas entre os macuas. Sob a liderança do clã Phiri, organizaram estados descentralizados, vistos pelos historiadores como confederações (Newitt, 1995:67-78; Pachai, 1972; Phiri, Kalinga, e Bhila, 2010). O Kalonga, sediado na margem ocidental do lago Marave (Niassa), era considerado a chefia proeminente e chamado "império" pelos portugueses (Phiri, 1975). Secessões na linhagem governante, no final do século XVI, conduziram à formação de duas outras formações políticas relevantes: o Lundu, implantado junto ao rio Chire (Schoffleers, 1968; 1987), e o Undi, com capital em Mano, a norte de Tete (Langworthy, 1969). Esses estados tinham sob a sua dependência "reinos" tributários, cujos chefes eram recrutados, inicialmente, entre os Phiri e, posteriormente, também entre outros clãs (Langworthy, 1969:150).

Conforme notava um observador português, no século XVIII, o estado Kalonga era diferente dos mais da "Costa d'Africa Oriental, porque em tudo prevalecem as femininas aos masculinos" (Castro, 1956:142 [1763]). Ele, provavelmente, estava a referir-se às matrilinhagens, grupos de parentesco que reivindicavam ser descendentes de uma mulher fundadora, sobre os quais estava estruturada a sociedade marave. Mas, aludia, também, ao lugar que as mulheres tinham nas instituições políticas.

As estruturas do estado Kalonga resultaram da aliança entre o recém-chegado clã Phiri, que controlava as chefias políticas, e o clã Banda, os senhores do território e dos santuários da fertilidade, que, através de chefias femininas, forneciam serviços rituais, nomeadamente as cerimónias da chuva (Phiri, 1975:46-76). Essas mulheres, que, em alguns casos, eram, conjuntamente, chefes dos territórios onde se situavam os santuários, tiveram um papel principal na construção do poder marave. Com efeito, alguns 
desses santuários, como Mbona e Mangadzi, tinham uma influência territorial vasta e não um carácter local (Langworthy, 1969:139-140). Mangadzi era considerada a antecessora e líder espiritual do clã Banda, tendo o seu papel sido transmitido às suas descendentes, que organizavam os santuários (Phiri, 1975:46-51, 76). Durante a formação do estado do Undi, Makewana, do clã Phiri, substituiu Mangadzi como líder espiritual, ajudando a suportar os poderes centrais do chefe undi. Makewana não tinha apenas funções religiosas. Em Msinga, onde se localizava o santuário, recebia tributos das populações $e$, ao contrário dos soberanos, dispunha de um conjunto de funcionários (Phiri, 1975:63; Langworthy, 1969:72-78; Ntara, 1973:41-42; ver também Kachapila, 2001).

No estado Kalonga, que não assentava num aparelho administrativo especializado (Langworthy, 1969:27), havia posições femininas muito importantes. A de nyangu, a mãe dos soberanos, era atribuída aos Phiri. Ela garantia a continuidade do grupo e, quando morria, tinha de ser prontamente substituída. O título de mwali, a mulher perpétua ou sénior do kalonga, pertencia necessariamente aos Banda, assegurando, assim, a sua participação no poder. Também no caso do falecimento de uma mwali, era de imediato nomeada outra, enquanto um novo kalonga era forçado a casar com a mwali do seu antecessor (Ntara, 1973:147-154; Phiri, 1975:55-57). A formação do estado do Undi implicou a expansão marave para oeste, para onde o novo chefe se deslocou com a linhagem kalonga, incluindo nyangu. Essa secessão deixou o Kalonga sem mães ou irmãs para fornecer novos soberanos. Em consequência, quando um kalonga morria, deslocava-se uma missão ao Undi para recrutar um sucessor, que tinha de ser aprovado pelos Banda (Ntara, 1973:21-22; Langworthy, 1969:147, 164; Phiri, 1975:55-57). Isso também demonstra a importância das mulheres na estrutura política dos estados maraves.

As funções destes cargos femininos estão muito pouco examinadas na literatura. Em primeiro lugar, porque os estudos se baseiam, especialmente, nas tradições orais recolhidas no século 
$\mathrm{XX}$, quando o poder político das mulheres já tinha enfraquecido por toda a África. ${ }^{21}$ Por exemplo, enquanto as tradições orais transmitidas pelos Banda ainda recordam mwali como sacerdotisa e chefe de um território, as recolhidas entre os Phiri representamna apenas como um título (Linden, 1972). Em segundo lugar, porque o papel das mulheres enquanto actores políticos não constituía um interesse central no inquérito dos autores. Na documentação portuguesa, encontram-se, analogamente, dados escassos sobre a questão. De facto, as relações da colónia portuguesa com as capitais do Kalonga e do Undi eram ténues e, ao contrário do que se passava com as cortes karangas, os portugueses não as frequentavam. Como informava um observador, só havia notícias sobre as suas "formalidades" por meio de "alguns Cafres, e Regulos, que com os nossos moradores negoceão" (Castro, 1956:139 [1763]). "Cafres" - o aportuguesamento de kaffir, a palavra árabe para os não crentes era como os portugueses denominavam os povos da costa oriental africana, à semelhança do que, antes deles, faziam os mercadores muçulmanos. $\mathrm{O}$ termo podia adquirir significados mais específicos, como nesse texto, em que se reporta aos súbditos de determinados chefes ou "régulos" - do latim regulus, "pequeno rei". Com efeito, esse era o nome por que no Estado da Índia, e portanto também em Moçambique, os portugueses nomeavam os chefes de pequenos territórios, distinguindo-os dos que classificavam como "imperadores" e "reis", as categorias políticas europeias empregues para soberanos que exerciam autoridade sobre territórios mais vastos. Era, portanto, por meio de alguns desses chefes com quem estabeleciam relações, tanto dependentes do kalonga quanto do undi, e dos seus súbditos que asseguravam as trocas mercantis que os portugueses adquiriam limitadas notícias das estruturas políticas daqueles estados.

O mesmo memorialista contava que o kalonga tinha muitas mulheres, das quais a "mais antiga" se chamava Muringa,

${ }^{21}$ Sobre esse enfraquecimento, ver, por exemplo, Hanson (2002); Saidi (2010); Wright (2004); Redding (2004). 
presumivelmente, aludindo a mwali. Conforme ele, Muringa não vivia com o kalonga, antes, tinha a sua própria corte e era "senhora absoluta p. ${ }^{\text {a }}$ determinar prémios e castigos aos moradores ou povos da sua jurisdição", dando conhecimento das suas decisões ao "Imperador seu marido, que sempre confirma" (Castro, 1956:140 [1763]). Assim, essa mulher governava também um território, possuía o seu conjunto de funcionários e usava jurisdição sobre determinadas populações. A mesma mulher exercia um papel principal na sucessão do kalonga, que era sempre aprovado por ela (Castro, 1956:142 [1763]). As restantes mulheres, chamadas concubinas pelos portugueses, tinham, contudo, poder suficiente para disputar os sucessores, como é sugerido por outra descrição:

Tem huma dó mulher com titulo de imperatriz, e hum grande numero de concubinas com tanta autoridade, que quando $o$ imperador não serve ja para os seus divertimentos, o tiram ou matão, e poem em seu lugar outro que ha de ser irmão, ou outro qualquer parente do sangue. ${ }^{22}$

O autor do texto evidenciava, desse modo, o carácter adélfico da sucessão, que recaía, de forma prescritiva, sobre um irmão ou outro parente masculino, de qualquer modo apurado entre a parentela matrilinear (Phiri, 1975:25-26). Abaixo do kalonga, lundu e undi, existiam dois ou três níveis de chefias, cuja designação variava consoante o estado (Phiri, 1975:73-76; Langworthy, 1969:26) e que incluíam chefias femininas, as quais, porém, não são valorizadas nos estudos sobre os maraves. Langworthy (1969:218-219), por exemplo, menciona apenas duas mulheres, Kawaza e Kathumba, cuja nomeação para a chefia de territórios integra no processo de expansão do Undi, defendendo que a sua escolha resultou da falta de familiares masculinos. As tradições recolhidas, no século XX, por Ntara (1973), cujo texto

22 "Descripção do Imperio de Manomogy, ou Caronga dalem, do Rio Zembeze", ant.2.03.1794, AHU, Moç., cx.66, doc.55. 
está mais próximo dos seus informantes, lembram, todavia, diversas governantes, algumas das quais passaram o poder a irmãos, justificam essas fontes, por serem mulheres.

A existência de mulheres governantes foi reportada pelo oficial português António Gamito, que percorreu o território do Undi no segundo quartel do século XIX. Conforme ele, essas chefes denominavam-se "fumo-acáze", i.e., "mulher que governa", as quais recebiam dos seus próprios súbditos deferências iguais às dos chefes homens (Gamito, 1937:I,37,103 [1854]). Fumu era a designação de determinado tipo de chefes (Langworthy, 1969:26), enquanto akazi significa "mulher" em várias línguas da região (Ntara, 1973:155). Gamito discorria sobre a existência de dois níveis de chefia: o mambo, um "chefe supremo [...] tem Fumos debaixo da sua obediência", enquanto o fumu correspondia a "um governador de distrito". Ele também anunciava que "n'esta ultima classe não sucedem homens a mulheres, e sempre sucedem umas ás outras por linha de successão" (Gamito, 1937:I,37 [1854]). Assim, entre os povos maraves, existiam chefaturas cuja liderança cabia sempre às fumuakazi, o que Gamito exemplificou com as quatro chefes que encontrou no seu itinerário: Insábue, Masinga, a irmã do poderoso Mucanda e Muenha (Gamito, 1937:I,16,33,112,178 [1854]).

O papel dessas mulheres está documentado para o século XVIII, no caso de sazora. A visibilidade desta chefia, da qual parece não haver rasto nas tradições orais, nem na literatura ${ }^{23}$, emergiu por volta de 1770, quando os moradores de Tete disputaram o domínio do seu território, situado não muito longe da margem esquerda do rio Zambeze, e contestaram o asilo que ela concedia aos escravos fugidos (Rodrigues, 2013). Esta chefe era nomeada, então, nas fontes portuguesas apenas como "Sazora" ${ }^{4}$,

\footnotetext{
${ }^{23}$ Conforme as fontes de Ntara, existia um chefe homem Sadzola na região do lago Marave (Ntara, 1973:60), portanto no estado Kalonga e não no Undi. Sosola é também o nome do último kalonga (Linden, 1972:11).

${ }^{24}$ Carta de sesmaria da terra Bamboe, 9.07.1771, AHU, cód.1335, fls.227v$229 \mathrm{v}$.
} 
começando a ser referida como "Princeza Sazora" na viragem para o século $\mathrm{XIX}^{25}$, e, finalmente, como uma "rainha" com os seus "Estados" (Botelho, 1835:265-266).

Na verdade, sazora era o título de uma chefe dependente do undi. Os seus embaixadores, por exemplo, informaram que ela "estava prompta para defender a terra aonde seu Pay Vnde tinha posto". ${ }^{26}$ Ela própria, interpelada pelos emissários dos moradores de Tete sobre as terras que ocupava, "respondeo, que ella tinha estado ali por ser a dita terra sua, mandada pello dito Rey Vnde, $e$ que assim não queria sahir dellas". ${ }^{27}$ Os discursos de sazora e dos seus embaixadores indicam que se tratava de uma chefia estabelecida pelo undi, provavelmente, ao nível dos amambo, cujo poder era legitimado por este soberano e a cujo clã Phiri, certamente, pertencia. De facto, ela era referida como "filha" na documentação coeva, o que, na linguagem classificatória do parentesco, podia equivaler apenas a "súbdita", mas acresce que o undi lhe dispensava um tratamento diferenciado. Em Julho de 1796, o soberano enviou uma embaixada ao governador dos Rios de Sena, para o informar que autorizava o castigo de todos os chefes maraves que abrigavam escravos fugidos, mas não "contra a Sazora sua filha, pois elle como Pay se obrigava a entregar nos os nossos escravos, que estivessem nas suas terras" ${ }^{28}$ Não importa aqui analisar a ambiguidade ou jogo do undi relativamente às ordens dadas a sazora para defender essas terras, enquanto asseverava aos moradores de Tete anuir às suas exigências. A história de sazora, cujo território foi, finalmente, conquistado, em 1803, ilumina a existência de chefias femininas maraves no século

\footnotetext{
${ }^{25}$ Relação das povoações da casa de Nicolau Pascoal da Cruz, 2.06.1801, AHU, Moç., cx.87, doc.1.

${ }^{26}$ Termo do adjunto dos moradores de Tete, 4.06.1803, AHU, Moç., cx.100, doc.9.

${ }^{27}$ Termo do adjunto dos moradores de Tete, 21.10.1798, AHU, Moç., cx.81, doc.87.

${ }^{28}$ Carta de Dionísio Araújo Bragança para João de Sousa e Brito, 20.07.1796, AHU, Moç., cx.74, doc.13.
} 
XVIII. A ausência de uma ampla informação sobre mulheres governantes no período anterior não significa, necessariamente, que elas não existiam, uma vez que, então, os portugueses não frequentavam assiduamente o território marave.

As sociedades macuas e suaílis do litoral eram menos hierárquicas do que as maraves e, sobretudo, que as karangas, não tendo constituído grandes estados, mas, antes, pequenas $e$ médias chefaturas (Hafkin, 1973; Medeiros, 1985; Martinez, 1989; Mbwiliza, 1991; Macaire, 1996; Geffray, 2000). Os estudos mostram que nessas chefaturas existiam, e existem, dois papéis fundamentais e paralelos: o mwene, formalmente o chefe político, e a pwyamwene, a líder espiritual conhecida por "mulher grande" ou "irmã mais velha do chefe", posição que pode ser atribuída a outra mulher. No caso dos mamwene e de outros chefes de aldeia, os mahumu, alguma literatura indica que esses cargos eram sempre exercidos por homens, e, até, que, nas sociedades suailis, as funções das apwyamwene eram tomadas pelos xeques locais (Mbwiliza, 1991:69-73). Pelo contrário, autores como Hafkin (1973:78-81), que adverte que pwyamwene significa literalmente "mulher governante", consideram que, no século XIX, para além de desempenharem esse cargo, as mulheres ocupavam, igualmente, o de mwene. No entanto, a generalidade dos autores reconhece a importância das apwyamwene. Elas eram, e são, consideradas, à semelhança das líderes espirituais maraves, como as antepassadas fundadoras da linhagem, as "mães das mães", e, enquanto tal, guardiãs da tradição, presidindo às cerimónias religiosas. Mas, o seu papel não era, nem é, apenas ritual, pois elas são as principais conselheiras dos chefes, nomeadamente em caso de guerra, e têm palavra na escolha dos sucessores. Nessas funções, elas próprias dispõem de um conjunto de mulheres que as aconselham (v.g. Zeballos, 2008; Geffray, 2000; Macaire, 1996:59-62; Martinez, 1989:7476).

O papel das mulheres enquanto mwene e apwyamwene nas sociedades costeiras com as quais os portugueses interagiram encontra-se melhor documentado para o século XIX e o início do 
século XX. ${ }^{29}$ Mas, em Setecentos, já era reportada a existência de chefaturas dirigidas por mulheres, como era o caso de salima ou sarima. Na década de 1780, a chefe Muduro chegou à Ilha de Moçambique. O governador de Moçambique identificou-a como "princesa", informando que ela usava o título de sarima. "Sarima" e "puia muhanno" (pwyamwene) eram, precisamente, as traduções apresentadas para "rainha" num dicionário inglês de Oitocentos (Bleek, 1856:16-17). Com efeito, os portugueses usavam a designação "rainha" para as mulheres de autoridade, quer elas tivessem o cargo de mwene, quer de pwyamwene, indistinção que também sugere a extensão dos poderes das apwyamwene.

Muduro fora enviada à ilha pelo chefe de Cambira para que as autoridades portuguesas a colocassem no seu quite, i.e., que lhe dessem posse como chefe da povoação de Nanapome e seus distritos, numa cerimónia que deveria ser conduzida pelo capitãomor português. ${ }^{30}$ Cambira designava o território de um conjunto de chefes a sudoeste da povoação portuguesa de Mossuril, sob a liderança de mocutomuno (Alpers, 1975:153-154). ${ }^{31}$ Muduro também era indicada pelo governador português como uma chefe marave. Provavelmente, o cargo de sarima resultava de alguma aliança com os macuas estabelecida pelos maraves no período em que faziam razias no litoral. Entre as chefes dos santuários maraves, estava Salima, localizada entre o rio Linphite e o lago Niassa (Ntara, 1973:12,22,116-118). Hafkin (1973:127), Mbwiliza (1991:108) e Bonate (2007:57-59), entretanto, consideram sarima uma mulher macua de Matibane, sob a autoridade do xeque de Quitangonha,

\footnotetext{
${ }^{29}$ Algumas mulheres são indicadas como apwyamwene, enquanto outras como chefes: Naguema de Namarral, Mwana Saiemo de M'tumalapa, Maziza de Meze ou M'Fatima de Sangage. Bonate (2007:57-59); Mattos (2014).

${ }^{30}$ Portaria de José Vasconcelos de Almeida, 24.07.1780, AHU, cód.1341, fl.67v.

${ }^{31} \mathrm{O}$ título de mocuto é, geralmente, associado a uma chefia namarral constituída no século XIX, mas a sua existência é anterior. No século XVIII, a liderança de mocutomuno sobre as chefaturas de Cambira foi reforçada pela administração portuguesa para enfrentar o poderoso chefe murimuno de Uticulo. Carta de Baltasar Pereira do Lago para o secretário de estado, 15.08.1776, AHU, Moç., cx.30A, doc.12.
} 
a norte da Ilha de Moçambique. De facto, documentação portuguesa posterior também refere uma $\mathrm{D}$. Sarima, identificada como a proprietária do território de Matibane. Em data incerta, ela pediu ao governo de Moçambique que lhe providenciasse uma quantia mensal para se sustentar a si e aos seus escravos domésticos e manter a sua "ostentação", devido à deserção e à morte da população do seu território. ${ }^{32}$ A referência a duas mulheres com o título de sarima no litoral da Ilha de Moçambique pode significar que o mesmo título existia em geografias distintas ou sugerir que Cambira exercia alguma tutela sobre Matibane no século XVIII.

De qualquer modo, o oficial inglês Henry Salt, que visitou a Ilha de Moçambique, em 1809, indicou Sancul, Quitangonha e Saurima como as chefaturas mais poderosas no litoral. Ele esclareceu que a última era governada por uma mulher, que comandava um largo distrito e conseguia colocar em campo 1500 soldados (Salt, 1816:41). Assim, a sarima Muduro e aquela reportada por Salt eram as líderes políticas daquela chefatura, as detentoras do cargo de mwene. Independentemente da sua origem, a figura de sarima evidencia a existência de mulheres governantes na região costeira de Moçambique no século XVIII.

Em suma, nas sociedades de parentesco matrilinear a norte do rio Zambeze, as mulheres detinham uma relevante participação política. Elas tiveram um papel notável na construção e no suporte dos estados maraves por meio dos santuários religiosos que controlavam, assim como ocupavam um lugar fundamental na estrutura desses estados, nomeadamente escolhendo os sucessores. Ao nível local, o seu poder parece ter sido mais amplo do que nos estados a sul do Zambeze, notando-se diversas mulheres a assumir o comando de chefaturas tanto entre os maraves como entre os macuas, tal como a ocupar a liderança religiosa em estreita interconexão com o exercício do poder político.

${ }^{32}$ Representação de D. Sarima, s.d., AHU, cx.266, doc.134. 


\section{Encontros coloniais: as donas do Zambeze}

As formas de autoridade pública que as mulheres exerceram nas sociedades africanas na área do rio Zambeze parece terem influenciado o poder que elas construíram no contexto da colonização portuguesa do vale. Aí, surgiram, desde o século XVII, figuras de mulheres poderosas, as donas de prazos. ${ }^{33} \mathrm{~A}$ designação "prazos" aplicava-se às terras que, tendo sido agregadas à coroa portuguesa, por conquista ou tratados de vassalagem com os chefes africanos, eram cedidas sob um regime jurídico que combinava as normas da enfiteuse com a concessão de bens da Coroa. O usufruto ou domínio útil dessas terras, cujo domínio directo permanecia nas mãos da Coroa, era cedido por três vidas, i.e., pela vida de três pessoas independentemente da posição geracional, com direito de renovação. Os beneficiários dessas concessões eram os moradores do território, uma categoria flexível que integrava indivíduos de origem europeia, outros nascidos no império, sobretudo em Goa, e mestiços naturais da África Oriental. ${ }^{34}$

As mulheres tornaram-se, também, senhoras dos prazos, inicialmente, de uma forma transitória, na qualidade de sucessoras de parentes, $e$, ainda no século XVII, por direito próprio, enquanto detentoras das cartas de aforamento passadas pela Coroa portuguesa. Nas últimas décadas do século XVIII, elas possuíam um conjunto de títulos superior àquele detido pelos homens. Sublinhe-se que a maioria dessas mulheres era mestiça, em função de uma colonização quase exclusivamente masculina, havendo, também, comprovadamente no século XVIII, mulheres

\footnotetext{
${ }^{33} \mathrm{Na}$ costa ocidental de África, na sequência da expansão europeia, também surgiram mulheres com bastante poder, mas baseado, principalmente, no comércio, no cultivo de menores áreas de terra e nas alianças com chefes locais. V. g. Caldeira (1999); Pantoja (2001); Brooks (2003); Havik (2004); Candido (2013); Oliveira (2015).

${ }^{34}$ Sobre os prazos como um regime jurídico híbrido, ver Rodrigues (2013). Para mais sobre os prazos, ver Capela (1995); Newitt (1973); Newitt (1995:217-242); Isaacman (1972).
} 
procedentes de Goa. O reconhecimento por parte da Coroa portuguesa da titularidade dos prazos nessas mulheres baseava-se no pressuposto de que os seus maridos seriam os cabeças-decasal, conforme o estipulado pela legislação portuguesa. No entanto, enquanto consorciadas, elas tinham uma participação activa na gestão das suas casas e assumiam-na na totalidade depois de viúvas, uma situação frequente, dada a elevada mortalidade dos homens europeus. Essas mulheres ficaram conhecidas por donas, uma forma de tratamento que se difundiu a partir das primeiras décadas de Setecentos e que indicava a sua pertença à elite local (Rodrigues, 2000; Rodrigues, 2015; Capela 1995: 67-102).

Os detentores dos prazos - os foreiros - possuíam jurisdição sobre esses territórios e as populações locais, delegada pela Coroa portuguesa e incorporada, até, em alguns dos títulos das terras concedidas. Essa competência foi revogada por uma carta régia de 1633, mas persistiu em algumas cartas de aforamento e estava expressa ou implícita em inúmeros documentos oficiais, como os regimentos dos governadores-gerais de Moçambique $e$, posteriormente, dos governadores dos Rios de Sena. Apesar de mitigada a partir das últimas décadas do século XVIII, com a complexificação do aparelho burocrático colonial, essa jurisdição continuou a integrar as práticas de administração dos prazos (Rodrigues, 2013:587-591,791-794). Tal jurisdição, legitimada pelas autoridades portuguesas, tinha de ser construída pelos próprios senhores e ser reconhecida pelos africanos, sem o que, dificilmente, eles a poderiam exercer. Nesse processo, os foreiros tanto usavam a negociação com as chefias dos africanos livres $e$ escravos, como, se necessário, empregavam os seus exércitos, cuja espinha dorsal assentava numa categoria de escravos designados achikunda (sobre esses escravos, v.g. Isaacman e Isaacman, 2004).

As mulheres não desempenharam cargos na administração portuguesa de Moçambique, de acordo com o modelo masculino do exercício dos postos, transposto de Portugal. Mas, como os foreiros varonis, elas adquiriram jurisdição sobre as terras $e$ as populações que as habitavam. As donas tinham de administrar as 
populações africanas desses territórios e manter as suas fronteiras em nome da coroa portuguesa. No entanto, o modo como exerciam o seu governo, de que dependia a sua aceitação pelas populações africanas, era enformado pelas práticas locais. Como outros chefes no vale do Zambeze, as donas extraíam dos habitantes das suas terras diversos tributos, em géneros e trabalho, colectavam multas relativas a processos judiciais e recrutavam pessoas para a guerra (Capela, 1995; Newitt, 1973; Newitt 1995:217242; Isaacman, 1972; Rodrigues, 2013). Muitas dessas mulheres construíram um protagonismo assinalável, ganhando, desse modo, o rótulo de "régulas", a designação portuguesa para os chefes africanos. ${ }^{35}$

Tal como os homens, também as donas mantinham relações com as chefias vizinhas, com quem algumas tinham eventualmente laços de parentesco, conquanto a documentação evidencie uma menor interacção a este nível. Com efeito, os foreiros masculinos, que assumiam cargos da hierarquia administrativa colonial, incluindo o comando dos exércitos em caso de guerra e a direç̧ão das relações diplomáticas com os chefes africanos, encontravam-se mais frequentemente em posição de liderar as negociações com os poderes africanos. A dinâmica dessas relações reflectia-se, reciprocamente, na sua posição como foreiros e como funcionários da Coroa portuguesa.

No entanto, assim como os outros senhores de prazos, as mulheres também desenvolveram formas de cooperação com as chefaturas africanas, no contexto de alianças políticas $e$ comerciais, ou enfrentaram-nas para defender os seus interesses, tal como o fizeram em relação à administração colonial. No final do século XVII, por exemplo, Vicência João, detentora do prazo Inhambanzo, em Tete, educou em sua casa um filho do mutapa Mukombwe, Nyamaende Mhande, baptizado como D. Pedro. Quando, em 1694, Nyamaende disputou o poder ao mutapa Nyakunembire, as terras de Vicência João foram o seu local de

\footnotetext{
${ }^{35}$ Para a biografia de algumas das mulheres, ver Capela (1995:67-102); Antunes (1995); Rodrigues (2000; 2015).
} 
refúgio temporário, tal como o apoio que ela lhe forneceu foi fundamental para ele conseguir ascender a mutapa (Rodrigues, 2013:246-248). D. Inês Gracias Cardoso, uma goesa detentora, entre outros, do prazo Gorongosa, agenciou tanto poder que um governador afiançava, em meados de Setecentos, que ela era a pessoa que conseguia impor "respeito" aos chefes africanos limítrofes do distrito de Sena, i.e., aos chefes do Barué, Quiteve e Manica. ${ }^{36}$ Numa ocasião, ela acolheu um membro de uma importante linhagem do Barué, que era perseguido pelo soberano makombe, assumindo a satisfação das suas dívidas (Miranda, 1955:226 [c.1766]). Ou seja, ela tanto fazia alianças como combatia os chefes vizinhos das suas terras, pelo que a sua autoridade era essencial para assegurar as fronteiras das terras da Coroa portuguesa. D. Inês conseguia impor o seu poder através dos seus exércitos de achikunda, que, tudo indica, chegou a capitanear, pelo menos contra as forças do governo-geral de Moçambique (Antunes, 1995). D. Francisca Josefa de Moura Meneses, moradora em Tete, foi outra mulher que interagiu fortemente com os chefes vizinhos. A sua fama chegou ao Kazembe (na actual Zâmbia), cujo soberano lhe enviou uma embaixada, a que ela correspondeu. $\mathrm{Na}$ sequência da participação dos seus escravos na viagem de travessia de África do paulista Dr. Francisco José de Lacerda e Almeida, que faleceu na corte daquele chefe, ela teve de negociar o resgate de parte desses cativos apreendidos por Mucanda, um dos mais importantes chefes maraves (Rodrigues, 2000).

As donas conseguiram construir uma notável autoridade sobre as populações que dominavam, livres e escravas, assim como obtiveram o reconhecimento do seu poder por chefaturas africanas limítrofes das suas terras e, até, algumas longínquas. Tudo indica que o domínio das culturas africanas e as relações com as populações locais, alicerçadas nas raízes que as suas famílias tinham na região, foram essenciais na construção do poder dessas mulheres. Será necessário considerar as fontes desse poder tendo em conta a interacção com as culturas políticas locais

${ }^{36}$ Carta de David Marques Pereira para o rei, 9.08.1758, AHU, cód.1320, fl.115. 
e a circulação de modelos de autoridade feminina entre as sociedades africanas $e$ a sociedade colonial.

Conclusão

Neste texto, procurei destacar como, à semelhança do que ocorreu noutras regiões de África (v.g. Aidoo, 1981:65-77; Farrar, 1997; Kaplan, 1997; Oyěwùmí, 1997; Bay, 1998; Hanson, 2002; Wright, 2004:418-421; Semley, 2011), as mulheres foram actores políticos centrais nas sociedades do sudeste africano. Com diferentes perfis de envolvimento, elas desempenharam cargos, quer no núcleo da administração central de vários estados, quer aos níveis regional $e$ local, tanto nas sociedades africanas, quanto nas áreas de colonização portuguesa. Essa participação política das mulheres, conquanto não tenha sido completamente ignorada, sobretudo no que respeita ao século XIX, só muito recentemente começa a ser valorizada nas investigações sobre essas sociedades, permitindo uma compreensão mais aprofundada do modo como funcionavam. Imperatrizes, rainhas, princesas, vakaranga, fumuakasi, mamwene, apwyamwene e donas foram retratadas pelas fontes portuguesas e, em alguns casos, pela tradição oral recolhida pelos estudiosos como importantes agentes políticos. Com efeito, em função das relações de género, as quais estavam embebidas nos laços de parentesco e também variavam segundo os contextos culturais, incluindo religiosos, havia papéis que eram preenchidos unicamente por homens, enquanto outros cabiam apenas a mulheres $e$, finalmente, alguns recaíam indistintamente em homens e mulheres. Como esses papéis se alteraram ao longo do tempo e se diferenciaram, ou não, em função do género é uma questão que necessita de ser aprofundada.

O papel dessas mulheres foi culturalmente específico e, por isso, não assumiu a mesma configuração em todas as sociedades aqui referidas. As classificações europeias usadas nas fontes portuguesas (imperatrizes, rainhas, infantas, etc.) não permitem, por vezes, apreender as formas de categorização local, nem o modo como elas operavam na prática. Em todas as grandes 
formações políticas, a que os portugueses chamavam "impérios", os principais cargos de autoridade, o de "imperadores", eram masculinos. Porém, tanto nas sociedades de descendência predominantemente patrilinear como naquelas de parentesco matrilinear, respectivamente, a sul e a norte do rio Zambeze, as mulheres exerceram formas de poder público.

$\mathrm{Na}$ administração central dos estados, as mulheres não tinham apenas influência. Elas actuavam em algumas áreas como governantes de direito próprio e não como esposas de soberanos ou na falta de herdeiros ou regentes masculinos, o que era, provavelmente, um entre outros mecanismos de balancear $\mathrm{o}$ poder dos soberanos. Em alguns estados, o seu papel era deliberativo na escolha dos sucessores, mesmo considerando que elas tinham de negociar com outros actores políticos. No caso do Quiteve, eram as próprias mulheres que assumiam o governo durante os interregnos e podiam prolongá-los no caso de não haver candidatos satisfatórios. Dado que as fontes referem que estas mulheres governavam os seus próprios territórios, eram importantes conselheiras dos soberanos e membros activos na sua escolha, parece que estas sociedades desenvolveram, pelo menos em alguns casos, práticas semelhantes às de co-governação existentes entre outros povos, como, por exemplo, os achantis da África Ocidental (v.g. Aidoo, 1985:65-77) e os ganda (Hanson, 2002).

As mulheres actuavam, igualmente, como governantes regionais. Em alguns casos, isso parece ter integrado práticas antigas de manter um equilibrio entre vários grupos possibilitando a sua participação no poder, como notou Hanson (2002:20) em relação a outros sistemas políticos em África. Noutros casos, a designação de mulheres pelos soberanos constituía um mecanismo para centralizar o poder $e$ evitar tendências secessionistas, integrando-se em modalidades hierárquicas mais rígidas. Ao nível de pequenas chefaturas, as mulheres podiam, analogamente, desempenhar o cargo de chefes, uma prática que foi adoptada entre os maraves e os macuas.

Provavelmente, a maior diferença entre as sociedades de parentesco patrilinear e matrilinear consideradas neste texto 
residia nas funções simbólicas e nas formas de autoridade religiosa que as mulheres assumiam mais notoriamente nestas últimas sociedades, conquanto o poder espiritual das mulheres, sobretudo das mais velhas, também existisse nas primeiras. Nas sociedades de parentesco matrilinear, as mulheres eram representadas intimamente ligadas à maternidade social, como fundadoras $e$ guardiãs das linhagens, desempenhando papéis religiosos que se articulavam com formas de autoridade pública, actuando, enfim, como co-governantes.

As formas de autoridade que as mulheres detinham nas sociedades africanas influenciaram, provavelmente, o poder que elas, mesmo as estrangeiras, construíram no território dominado pela coroa portuguesa, em particular, no vale do Zambeze. Num contexto de fluidez de fronteiras e de constante interacção com as sociedades locais, as donas dos prazos, contra a expectativa da Coroa portuguesa ao conceder-lhes títulos de terras, tiveram um sucesso assinalável na afirmação da sua autoridade.

Neste texto, tentei, particularmente, evidenciar que as mulheres exerciam formas de poder político no sudeste da África Oriental. São necessários mais estudos para compreender como o poder era entendido e praticado nestas sociedades e como as questões de género eram incorporadas nas instituições políticas. $\mathrm{O}$ aprofundamento da investigação, considerando as fontes escritas $e$ orais, permitirá apreender as especificidades da participação política das mulheres nestas sociedades e como ela se alterou ao longo do tempo.

\section{Fontes impressas}

BleEK, Wm. H. J. The Languages of Mosambique. Londres, Harrison and Sons, 1856.

Bocarro, António. Década 13 da Historia da India. Lisboa, Academia das Sciencias de Lisboa, 1876 [c.1635].

BotelHo, Sebastião Xavier. Memória estatística sobre os domínios portugueses na África Oriental. Lisboa, Tipografia José Baptista Morando, 1835. 
CASTRO, Dionízio de Mello e. Notícia do Império Marave e dos Rios de Sena [1763]. In: DiAS, Luiz Fernando de Carvalho (ed.). Fontes para a História, Geografia e Comércio de Moçambique (Séc. XVIII). Lisboa, JIU, 1956, pp.119-149.

Conceição, Fr. António. Tratado dos Rios de Cuama [1696]. O Chronista de Tissuary (II), Goa, 1867, pp.39-45; 63-69; 84-92; 105111.

DoCUMENTOS sobre os Portugueses em Moçambique e na África Central. Lisboa, CEHU/NAR, 1975, VIII, pp.34-58.

FERRÃO, [Francisco Henriques]. Account of the Portuguese Possessions within the Captaincy of Rios de Senna [a.1823]. In: OWEN, W. F. W. Narrative of voyages to explore the shores of Africa, Arabia and Madagascar. Londres, Richard Bentley, 1833, pp.401-420.

Gamito, A. C. P. O Muata Cazembe e os Povos Maraves, Chevas, Muizas, Muembas, Lundas e outros da África Austral. Diário da expedição portuguesa comandada pelo major Monteiro e dirigida àquele imperador nos anos de 1831 e 1832. Lisboa, AGC, 1937 [1854].

MiRANDA, António Pinto de. Monarchia Africana [c. 1766]. In: ANDRADE, António Alberto Banha de (ed.). Relações de Moçambique Setecentista. Lisboa, AGU, 1955, pp.303-312.

MonTEZ, Caetano (org.). Inventário do Fundo do Século XVIII. Separata de Moçambique. Documentário Trimestral (72-92), Lourenço Marques, 1958.

PACHECO, Albino. Uma viagem de Tete ao Zumbo (1864). Boletim Oficial de Moçambique (21), 1883, pp.147-149.

"RESPOSTA das questoens sobre os cafres" ou Notícias etnográficas sobre Sofala do fim do século XVIII [c.1794]. Lisboa, JIU, 1966. Introdução e notas de Gerhard Liesegang.

SAlt, Henry. A voyage to Abyssinia, and travels into the interior of that country, executed under the orders of the British government, in the years 1809 and 1810. Philadelphia, M. Carey; Boston, Wells \& Lilly, 1816. 
SANTOS, Frei João dos. Etiópia Oriental e Vária História de Cousas Notáveis do Oriente. Lisboa, CNPCD, 1999 [1609]. Introdução de, Manuel Lobato; notas de Manuel Lobato e Eduardo Medeiros.

SILVA, João Julião da. Memoria sobre Sofalla [1844]. In: FELICIANO, José Fialho; Nicolau, Victor Hugo (ed.). Memórias de Sofala. Lisboa, CNCDP, 1998, pp.27-136.

SiLVA, Manuel Galvão da. Diario das Viagens feitas pelas terras de Manica por Manoel Galvão da Silva em 1790 [1790]. In: DIAS, Luiz Fernando de Carvalho (ed.). Fontes para a História, Geografia e Comércio de Moçambique (Séc. XVIII). Lisboa, JIU, 1956, pp.323332.

\section{Referências bibliográficas}

AIDOO, Agnes. Asante Queen Mothers in Government and Politics in the Nineteenth Centhury. In: STEADY, Filomina Chioma (ed.). The Black Woman Cross-Culturally. Cambridge, Shenkman, 1981, pp.65-77.

AlPers, Edward A. Ivory \& Slaves in East Central Africa. Changing Patterns of International Trade to the Later Nineteenth Century. Londres, Heinemann, 1975.

ANTUNES, Luís Frederico Dias. D. Ignez Gracias Cardozo: uma mulher de armas. In: O rosto feminino da expansão portuguesa. Congresso internacional. Lisboa, Comissão para a Igualdade e para os Direitos das Mulheres, 1995, I, pp.789-798.

BAy, Edna G. Wives of the Leopard: Gender, Politics, and Culture in the Kingdom of Dahomey. Charlottesville, University of Virginia Press, 1998.

BEACH, David N. The Shona and the Zimbabwe 900-1850. Londres, Heineman, 1980.

The Shona and their Neighbours. Oxford UK, Blackwell Publishers, 1994.

BHILA, H. H. K. Trade and Politics in a Shona Kingdom. The Manyika and their African and Portuguese Neighbours 1575-1902. Harlow \& Salisbury, Longman, 1982. 
BONATE, Liazzat J. K. Traditions and transitions: Islam and chiefship in Northern Mozambique, ca. 1850-1974. Tese (Doutorado em Estudos Históricos), University of Cape Town, Cidade do Cabo, 2007.

BROOKS, George E. Eurafricans in Western Africa. Commerce, Social Status, Gender, and Religious Observance from the Sixteenth to the Eighteenth century. Athens, Ohio University Press, 2003.

BuIJS, Gina. Gender and Person in African Societies: The Role of Hermeneutics. Alternation. Interdisciplinary Journal for Study of the Arts and Humanities in Southern Africa (9:1), Durban, University of KuaZulu Natal, 2002, pp.57-73.

CAldeIRA, Arlindo. Mulheres, Sexualidade e Casamento em São Tomé e Príncipe (Séculos XV-XVIII). Lisboa, Edições Cosmos, 1999.

CANDido, Mariana P. An African Slaving Port and the Atlantic World. Benguela And Its Hinterland. Nova Iorque, Cambridge University Press, 2013.

Women, family, and landed property in nineteenth-century Benguela. African Economic History (43), Madison, 2015, pp.136161. Número especial African women's access and rights to property in the Portuguese empire, editado por Mariana Candido e Eugénia Rodrigues.

CAPEla, José. Donas, Senhores e Escravos. Porto, Afrontamento, 1995.

FARRAR, Tarikhu. The Queenmother, Matriarchy, and the Question of Female Political Authority in Precolonial West African Monarchy. Journal of Black Studies (27:5), Filadélfia, Temple University, 1997, pp.579-597.

GefFray, Christian. Nem pai nem mãe. Crítica do parentesco: o caso macua. Lisboa, Caminho, 2000.

HAFKIN, Nancy Jane. Trade, society and politics in Northern Mozambique, c.1753-1913. Tese (Doutorado em História), Boston University, 1973.

HANSON, Holly. Queen Mothers and Good Government in Buganda: The Loss of Women's Political Power in Nineteenth-Century East Africa. In: Allman, Jean; GEIGER, Susan; MusisI, Nakanyike (eds.). Women in African colonial histories. Bloomington, Indiana University Press, 2002, pp.19-236. 
HANRETTA, Sean. Women, Marginality and the Zulu State: Women's Institutions and Power in the Early Nineteenth Century. The Journal of African History (39:3), Cambridge, 1998, pp.389-415.

HAVIK, Philip J. Silences and Soundbytes. The gendered dynamics of trade and brokerage in the pre-colonial Guinea Bissau region. Münster, Lit Verlag, 2004.

Herbst, Jeffrey. States and Power in Africa. Comparative Lessons in authority and control. Princeton, Princeton University Press, 2000.

ILIFFE, John. Africans: The History of a Continent. Cambridge, Cambridge University Press, 1997 [1995].

ISAACMAN, Allen F. Mozambique: The Africanization of a European Institution; the Zambesi Prazos, 1750-1902. Madison, University of Wisconsin Press, 1972.

; ISAACMAN Barbara S. Slavery and Beyond. The making of Men and Chikunda Ethnic Identities in the Unstable World of SouthCentral Africa, 1750-1920. Portsmouth, Heinemann, 2004.

JUNOD, Henri. Usos e Costumes dos Bantu. Maputo, Arquivo Histórico de Moçambique, 1996 (2 ts.).

KACHAPILA, Hendrina. "Remarkable adaptability": gender, identity, and social change among the Chewa of Central Malawy, 1870-1945. Tese (Doutorado em História), Dalhouisie University, Halifax, 2001.

KaPlan, Flora Edouwaye (ed.). Queens, Queen Mothers, Priestesses and Power: Case Studies in African Gender. Annals of the New York Academy of Sciences, (810), Nova Iorque, New York Academy of Sciences, 1997.

Kopytoff, Igor (ed.). The African Frontier. The Reproduction of Traditional African Societies. Bloomington and Indianapolis, Indiana University Press, 1987.

LANGWORTHY III, Harry Wells. A history of Undi's kingdom to 1890: aspects of Chewa history in East Central Africa. Tese (Doutorado em História), Boston, Boston University, 1969.

LEVIN, George Gregor. Women and the Second Estate in 16th Century Zambezia: Gendered Powers, a "Puppet" African Queen and Succession in vaKaranga Society, 1500-1700. Tese (Mestrado em 
História), San Luis Obispo, The Faculty of California Polytechnic State University, 2013.

LINDEN, Ian. Mwali and the Luba origin of the Chewa: some tentative suggestions. The Society of Malawi Journal (25:1), Blantyre, 1972, pp.11-19.

MACAIRE, Pierre. L'Héritage Makhuwa au Mozambique. Paris, L'Harmattan, 1996.

MACGAFFEY, Wyatt. Changing representations in Central African History. The Journal of African History (46:2), Cambridge, 2005, pp.189-207.

. A note on Vansina's invention of matrilinearity. The Journal of African History (54:02), Cambridge, 2013, pp.269-280.

MACGONAGLE, Elizabeth. Crafting identity in Zimbabwe and Mozambique. Rochester, University of Rochester Press, 2007.

MARTINEZ, Francisco Lerma. O Povo Macua e a sua Cultura. Lisboa, IICT, 1989.

MATTOS, Regiane Augusto de. Poder e estratégias políticas no norte de Moçambique: a relação entre as pia-mwene e o governo português no final do século XIX. Anos 90 (21:40), Porto Alegre, Universidade Federal do Rio Grande do Sul, 2014, pp.61-110.

MBWILIZA, J. F. A history of commodity production in Makuani, 16001900. Dar es Salaam, Dar es Salaam University Press, 1991.

MEDEIROS, Eduardo. O sistema linhageiro macua-lómwè. Maputo, Universidade Eduardo Mondlane, 1985.

Mtetwa, Andrew Hama. A history of Uteve under the mwene mutapa rulers 1480-1834: a re-evaluation. Tese (Doutorado em História), Evanston, Northwestern University, 1984.

Mudenge, S.I.G. A political History of Munhumutapa c 1400-1902. Harare, Zimbabwe Publishing House, 1988.

NEWITT, M.D.D. Portuguese settlement on the Zambesi. Londres, Longman, 1973.

. A History of Mozambique. Londres, Hurst \& Company, 1995.

NTARA, Samuel Josia. The History of the Chewa (Mbiri ya Achewa). Wiesbaden, Franz Steiner Verlagh, 1973. Ed. de Beatrix HEINTZE, 
comentários de, Harry W. Langworthy, tradução de W. W. Kamphandira Jere.

OliveIRA, Vanessa S. Gender, Foodstuff Production and Trade in LateEighteenth Century Luanda. African Economic History (43), Madison, 2015, pp.57-81. Número especial African women's access and rights to property in the Portuguese empire, editado por Mariana Candido e Eugénia Rodrigues.

OYĚWÙMÍ, Oyèrónkẹ. The Invention of Women: Making an African Sense of Western Gender Discourses. Minneapolis, University of Minnesota Press, 1997.

PABIOU-DUCHAMP, Florence. Être femme de rois karanga à la fin du XVI et au début du XVII siècle. Revue Lusothopie (XII:1-2), Leiden, Brill, 2005, pp.101-104.

PACHAI, Bridglal (ed.). The Early History of Malawi. Londres, Longman, 1972.

PANTOJA Selma. "Donas de "Arimos": Um negócio feminino no abastecimento de géneros alimentícios em Luanda (séculos XVIII e XIX). In: PANTOJA, Selma. (ed.) Entre Áfricas e Brasis. Brasília, Paralelo, 2001, pp.35-49;

PHIRI, Kings Mbacazwa. Chewa history in Central Malawi and the use of oral tradition, 1600-1920. Tese (Doutorado em História), Madison, University of Wisconsin, 1975

PhiRI, K. M.; KalingA, O. J.; BHILA, H. H. K. A Zambézia do Norte: a região do Lago Malaui. In: OGot, Bethwell Allan. (ed.) África do século XVI ao XVIII, v. V da História geral da África. Brasília, UNESCO, 2010, pp.719-754.

PIKIRAYI, Innocent. The Zimbabwe Culture. Origins and Decline of Southern Zambezian States. Walnut Creek, Altamira Press, 2001.

REDDING, Sean. Women and Gender Roles in Africa since 1918: Gender as a Determinant of Status. In: MEAD, Teresa A.; WIESNER-HANKS, Merry E. (eds.) A Companion to Gender History. Malden, Blackwell Publishing, 2004, pp.540- 554.

RODRIGUES, Eugénia. Chiponda, a senhora que tudo pisa com os pés. Estratégias de poder das donas dos prazos do Zambeze no século 
XVIII. Anais de História de Além-Mar (I), Lisboa, CHAM, 2000, pp.101-132.

. Embaixadas portuguesas à corte dos mutapa. In: CARNEIRO, Roberto; MATOS, Artur Teodoro de. (coord.) D. João III e o Império. Lisboa, CHAM/CEPCEP, 2004, pp.753-779.

. Portugueses e Africanos nos Rios de Sena. Os Prazos da Coroa em Moçambique nos Séculos XVII e XVIII. Lisboa, Imprensa Nacional-Casa da Moeda, 2013.

. Women, land, and power in the Zambezi valley of the eighteenth century. African Economic History (43), Madison, 2015, pp.19-56. Número especial African women's access and rights to property in the Portuguese empire, editado por Mariana Candido e Eugénia Rodrigues.

ROQue, Ana Cristina. Terras de Sofala: persistências e mudança. Contribuições para a história da costa sul-oriental de África nos séculos XVI-XVIII. Lisboa, Fundação Calouste Gulbenkian, 2012.

RosÁRIO, Carmeliza Soares da Costa. Another Time, Another Place: Memory of Female Power and Authority from the Zambezi Valley, Mozambique. African Economic History (43), Madison, 2015, pp.196215. Número especial African women's access and rights to property in the Portuguese empire, editado por Mariana Candido e Eugénia Rodrigues,

SAIDI, Christine. Women's Authority and Society in Early East-Central Africa. Nova Iorque, University of Rochester Press, 2010.

SCHOFFLEERS, J. M. Symbolic and social aspects of spirit worship among the Mang'anja. Tese, Oxford, Oxford University, 1968.

SCHOFFELEERS, J. Matthew. The Zimba and the Lundu state in the late sixteenth and early seventeenth centuries. The Journal of African History (28:3), 1987, pp.337-355.

SEMLEY, Lorelle D. Mother Is Gold, Father Is Glass. Gender and Colonialism in a Yoruba Town. Bloomington, Indiana University Press, 2011.

Stephens, Rhiannon. A History of African Motherhood: The Case of Uganda, 700-1900. Nova Iorque, Cambridge University Press, 2013. 
VANSINA, Jan. Paths in the Rainforests. Toward a History of Political Tradition in Equatorial Africa. Madison, The University of Wisconsin Press, 1990.

WRIGHT, Marcia. Gender, women, and power in Africa, 1750-1914. In: MEAD, Teresa A.; WIESNER-HANKS, Merry E. (ed.). A Companion to Gender History. Malden, Blackwell Publishing, 2004, pp.418-421.

ZEBALlOS, Ivanna Marcela Arizcurinaga. Importância Actual da Apwiyamwene no Ambito Tradicional e Político. Nampula, Diname E.E., 2008.

ZIMBA, Benigna. Achivanjila I and the Making of the Niassa Slave Routes. In: ZiMBA, Benigna; AlPERS, Edward; IsAACMAN, Allen (eds.). Slave Routes and Oral Tradition in Southeastern Africa. Maputo, Filsom Entertainment, 2005, pp.219-251.

ZimBA Benigna. Mulheres invisiveis: O Género e as Políticas Comerciais no Sul de Moçambique, 1720-1830. Maputo, Promédia, 2003. 